\title{
Глубокоуважаемые коллеги!
}

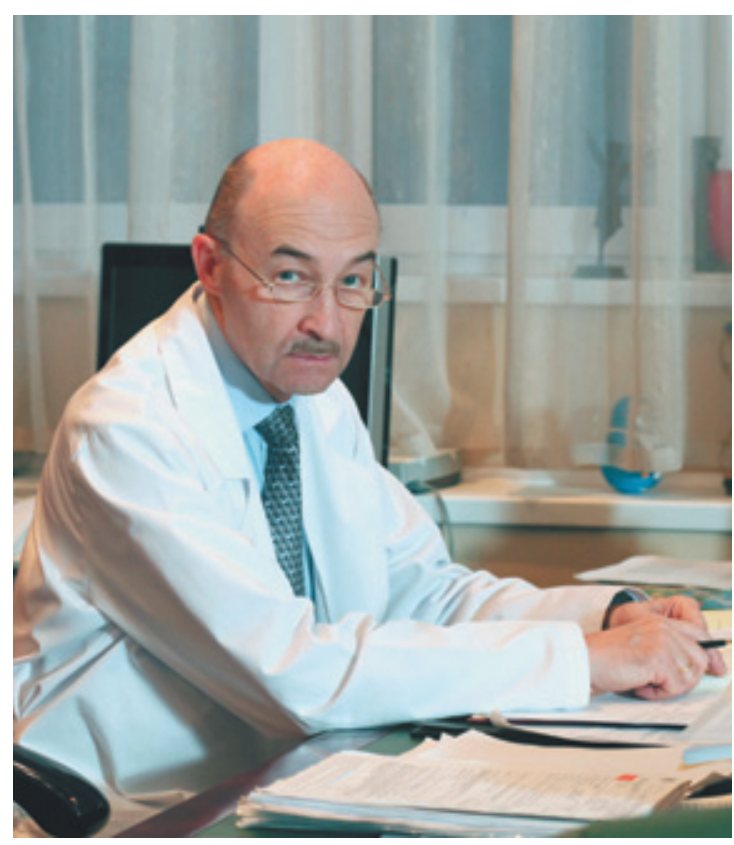

Вашему вниманию представлен четвертый выпуск нашего журнала за 2014 год. «Вестник трансплантологии и искусственных органов» издается ровно 15 лет, с 1999 года. Впрочем, реальная история журнала началась еще раньше. 20 лет назад, в 1994 году, по инициативе и под руководством академика В.И. Шумакова был начат выпуск журнала «Трансплантология и искусственные органы», преемником и продолжателем которого является наш «Вестник». Валерий Иванович Шумаков был главным редактором журнала со дня основания до 2008 года.

В журнале публикуются обзорные и оригинальные статьи по фундаментальным и прикладным проблемам трансплантологии, регенеративной медицины; работы, посвященные разработке, экспериментальному изучению и клиническому применению искусственных органов, биогибридных систем и материалов; информация о наиболее значимых научно-практических событиях в этой области.

Журнал «Вестник трансплантологии и искусственных органов» является единственным специализированным изданием, в котором могут быть опубликованы работы по специальности 14.00 .41 - трансплантология и искусственные органы (медицинские и биологические науки). Однако реально он охватывает значительно более широкое информационное поле. Особенностью нашей специальности является ее комплексность: трансплантология и наука об искусственных органах объединяют клинические (кардиология, нефрология, гастроэнтерология, хирургия, и др.), медико-биологические (иммунология, патофизиология и др.) и даже медико-технические дисциплины. В то же время ни одна из перечисленных специальностей в полной мере не может отражать сущность и специфику научных работ по трансплантологии и искусственным органам, что и объясняет уникальность настоящего издания.

Наш «Вестник» входит в действующий в настоящее время Перечень рецензируемых научных журналов и изданий, рекомендуемых ВАК Министерства образования и науки Российской Федерации для публикации основных научных результатов диссертаций на соискание ученой степени доктора и кандидата наук, с момента формирования последнего.

Много сделано для повышения статуса журнала и качества публикуемых материалов: расширен состав редакционной коллегии, улучшен дизайн издания, повышены требования к порядку рецензирования. Существенно улучшились наукометрические показатели. Наличие цифрового идентификатора DOI придает журналу более высокий статус, повышает возможность доступа и получения корректной информации о каждой статье.

Мы с оптимизмом смотрим в будущее. От имени членов редколлегии, редакционного совета, сотрудников редакции желаю авторам и читателям нашего журнала творческих успехов в наступающем 2015 году.

С уважением

главный редактор журнала,

директор ФГБУ «Федеральный научный изентр

трансплантологии и искусственньх органов

имени академика В.И. Шумакова» Минздрава России,

главный специалист трансплантолог Минздрава России,

председатель Российского трансплантологического общества,

академик РАН

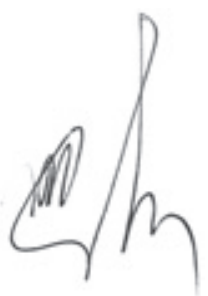

C.B. Гombe 